Pianta, R. C. \& Hamre, B. K. (2009). “Conceptualisation, measurement and improvement of classroom processes: Standardised observation can leverage capacity”. Educational Researcher, 1. 38/2, 109-119.

Peter, Serdyukov. (2016). "Innovation in education: what works, what doesn’t, and what to do about it?" Journal of Research in Innovative Teaching \& Learning, 1, 4-33. [Online]: https://doi.org/10.1108/JRIT-10-2016-0007

Robinson, K. (2016). Creative Schools: The Grassroots Revolution That's Transforming Education. Penguin books. New York.

\title{
TIMENKO M.
}

Institute of Pedagogy of the National Academy of Pedagogical Sciences of Ukraine, Kyiv, Ukraine

\section{ST CENTURY SKILLS IN SCHOOL EDUCATION IN THE UNITED KINGDOM}

The author of the article considers and characterizes the main current trends in the development of school education in the UK. The author describes the necessary skills of the XXI century for students of secondary schools in Great Britain and the conditions of their formation. These are skills such as: joint problem solving, responsibility, critical thinking, creativity, emotional intelligence, cooperation, decision making, IT skills, self-regulation, communication, flexibility and adaptability, respect, information and economic literacy, etc. The author also describes the so-called soft skills (flexible) and hard skills (hard). The article notes the role of the 21st century teacher, which today cannot be limited to knowledge transfer, but to focus, discuss and, of course, evaluate students' progress so that they know when more support is needed, as today's innovative schools design classes for knowledge. , not its transportation.

It is argued that modern and relevant and key skills of the 21st century include: problem solving, critical thinking, creativity, collaboration, decision making, IT skills, self-regulation, communication, respect, information and economic literacy, which in turn require appropriate teaching methods of the 21st century. The role of teachers can no longer be limited to knowledge transfer, but should be well-guided, discussed and, of course, evaluated by students' progress so that they know when more support is needed. Today, innovative schools design classrooms for the pursuit of knowledge, not its transportation.

Key words: skills, school education, Great Britain, tendencies

Стаття надійшла до редакції 12.10.2020 р.

УДК 378.091 .39

https://doi.org/10.33989/2075-146x.2020.26.227655

\section{ГАЛИНА ТИМЧЕНКО}

ORCID: 0000-0002-7279-7173

ГЕЛЕНА НЕУСТРОСВА

ORCID: 0000-0001-9183-7225

Національний технічний університет «Харківський політехнічний інститут»

\section{НАТАЛІЯ ПОНОМАРЕНКО}

ORCID: 0000-0001-6399-1321

Український державний університет залізничного транспорту, м. Харків

\section{ПРОЄКТНА ДІЯЛЬНІСТЬ СТУДЕНТІВ ТА КРИТЕРІї ОЦІНЮВАННЯ ЇЇ РЕЗУЛЬТАТІВ}

\begin{abstract}
У статті розглядаються питання організації проєктної роботи студентів як сучасного підходу, що дозволяє інтегрувати теоретичні знання і практичні навички, необхідні для роботи в сучасних умовах. Проєктна діяльність є однією 3 форм організації навчального процесу, сприяє підвищенню якості освіти, демократизації стилю спілкування викладачів і студентів. Метою проєктної діяльності є створення умов для формування дослідницьких умінь студентів, розвитку їх творчих здібностей та логічного мислення. У представленій роботі надано практичні рекомендації викладачам, які хочуть використовувати проєкти в своїх курсах.
\end{abstract}

Ключові слова: проєктна робота, студенти, викладач, критерій, оичінка, дослідний проєкт, практичний проєкт, освітня програма

Проєктна діяльність студентів сприяє розвитку самостійних дослідницьких умінь, творчих здібностей і логічного мислення, інтегрує знання, отримані в ході навчального процесу, і залучає їх до вирішення конкретних життєво важливих проблем. Проєктна робота дозволяє студентам поєднувати разом різні елементи знань, які підходять для 
вирішення обраної проблеми. Кожна проєктна робота індивідуальна і на схожа на іншу. Ці проєкти дуже складні для оцінки, оскільки кожен проєкт унікальний. Це величезна проблема, яка передбачає багато ресурсів для викладачів, які збираються оцінювати проєкти, оскільки зміст різних проєктів часто вимагає різних критеріїв оцінювання, які все одно повинні узгоджуватися 3 ціллю навчання. Як наслідок, хоча освіта впроваджує інновації у галузі нових дисциплінарних та міждисциплінарних знань, досліджень та технологій, а також у нових педагогічних підходах для задоволення потреб, їй все ще бракує корисних методів оцінки (Crewley, Malmquist, Østlund, \& Brodeur, 2007; Красноборова, 2010). Кількість літератури, що стосується різних підходів до оцінки, показує, що існує багато корисних концепцій і методів (Palomba, \& Trudy, 1999; Kolmos, Fleming, Lone). Для роботи над проєктами доступний ряд різних методів оцінювання, які можуть бути використані для оцінки ряду різних навичок та для оцінки, як формуючої, так i підсумкової, різними оцінювачами. Ці підходи до оцінювання враховують різні результати навчання: технічні знання, вирішення проблем, спілкування, робота в команді, самостійне навчання тощо (PBLE (Project Based Learning in Engineering)). У роботах (Pedersen, \& Kofoed; Stachowicz, \& Kofoed) представлено досвід двох випадків: оцінювання перших курсів проєктів з курсу медіалогії, Університет Ольборг (AAU) та проєктів третього курсу з Електричного та відділ обчислювальної техніки Університету Міннесоти Дулут (UMD), відповідно. Обговорюються методи оцінки, що використовуються у двох випадках. Крім того, представлені очікування студентів та досвід викладачів щодо методів, що використовуються для оцінки проєктів.

Проєктна діяльність студентів є невід'ємною частиною освітньої програми; ії організація спрямована на створення умов, при яких студенти зможуть застосовувати на практиці отримані ними теоретичні знання, розвивати Soft Skills i професійні навички, передбачені освітньою програмою, в ситуаціях (умовах) практичної та/або дослідницької діяльності.

Проєктна діяльність дозволяє:

- зробити процес навчання максимально наближеним до практичної діяльності;

- підвищити мотивацію до навчання;

- індивідуалізувати навчальний процес і зробити його більш інтенсивним;

- накопичувати студентам досвід для включення в самостійну професійну діяльність;

- створювати умови для формування професійних компетенцій студентів.

Кожен проєкт повинен бути обмеженим у часі, мати чіткі критерії результату, припускати зовнішнє або внутрішнє замовлення (запит) на одержуваний результат. Типи проєктів, які можуть бути реалізовані в рамках освітньої програми, розрізняються залежно від цілей, характеру роботи і отриманих результатів, а також за способом організації.

3 точки зору цілей і результатів можна розрізняти такі типи проєктів:

- Дослідницький (науково-дослідний) проєкт, основною метою якого є проведення дослідження. Передбачає отримання в якості результату наукового або науково-прикладного продукту (статті / публікації, звіту, аналітичного огляду або записки, заявки на науковий грант, методичного посібника тощо); (виконується на кафедрі)

- Практико-орієнтований (прикладний) проєкт, основною метою якого є вирішення прикладної задачі, найчастіше за запитом зовнішнього по відношенню до Університету замовника (договір про дуальну освіту 3 суб' єктом господарювання).

3 точки зору способів організації виділяються наступні типи проєктів:

- Індивідуальний - проєкт, який може бути виконаний одним учасником (передбачає індивідуальну роботу);

- Груповий - проєкт, який виконується командою учасників (передбачає колективний результат);

- Короткостроковий - проєкт, що вкладався в рамки одного навчального семестру,

- Довгостроковий - проєкт, що передбачає тривалу участь (понад семестру),

- З Зовнішній - проєкт, що виконується за договором про дуальну освіту на підприємстві (в компанії),

- Внутрішній - проєкт, що виконується на кафедрах Університету.

Основні учасники та їх завдання:

- Куратор проєкту - відповідальна особа, яка контролює хід виконання проєкту, оцінювання внеску учасників проєкту та оформлення навчальної документації в ході та за підсумками проєкту; Куратор проєкту - працівник Університету;

- Наставник проєкту - відповідальна особа, яка контролює хід виконання проєкту від суб'єкта господарювання; Наставник проєкту - працівник Підприємства (Компанії); у разі якщо проєктна робота зовнішня;

- Учасник проєкту - студент (група студентів), що безпосередньо бере участь у реалізації проєкту.

Куратор проєкту відповідає за організацію та реалізацію проєкту; в його обов'язки входить виконання таких функцій:

- $\quad$ розробка і / або уточнення технічного завдання проєкту (самостійно або спільно з наставником проєкту);

- розробка плану-графіка проєкту (спільно з учасниками проєкту);

- при необхідності - розподіл обов'язків учасників проєкту;

- допомога в організації та реалізації проєкту за запитом учасників, допомога в залученні до участі в проєкті профільних фахівців і т.і .;

- організація публічного представлення результатів проєкту;

- оцінка роботи учасників проєкту (враховуючи оцінку їх звітів по проєкту, за заздалегідь визначеними критеріями);

- $\quad$ оформлення навчальної документації по проєкту (оціночного листа і т.і.). 
Істотний момент в проєктуванні і реалізації проєкту - оцінка його ефективності. Характер оцінки залежить від типу проєкту, від його теми, умов реалізації (Стрекалова, 2013).

У таблиці 1 наведено критерії, які можна використовувати при оцінюванні дослідних проєктів.

Критерії, які можна використовувати при оцінюванні дослідних просктів

\begin{tabular}{|c|c|}
\hline $\begin{array}{c}\text { Рекомендовані до } \\
\text { оцінювання складові проєкту }\end{array}$ & Критерії для оцінювання \\
\hline $\begin{array}{l}\text { Постановка проблеми і їі } \\
\text { обгрунтованість }\end{array}$ & $\begin{array}{l}\text { • актуальність, теоретична і практична значущість теми } \\
\text { дослідження; } \\
\text { • } \quad \text { постановка і обгрунтованість проблеми дослідження. }\end{array}$ \\
\hline $\begin{array}{c}\text { Проведення теоретичного } \\
\text { дослідження }\end{array}$ & 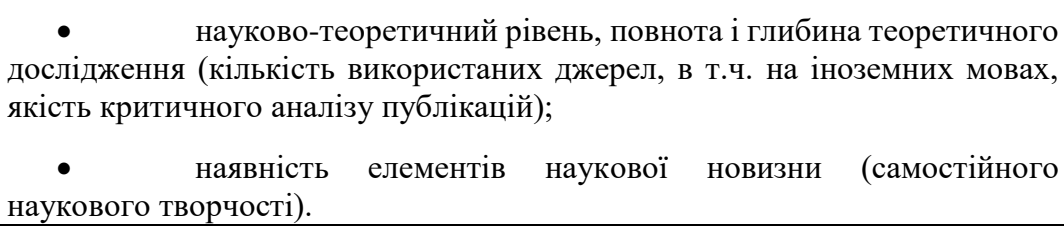 \\
\hline $\begin{array}{r}\text { Результат виконання } \\
\text { дослідницького проєкту }\end{array}$ & 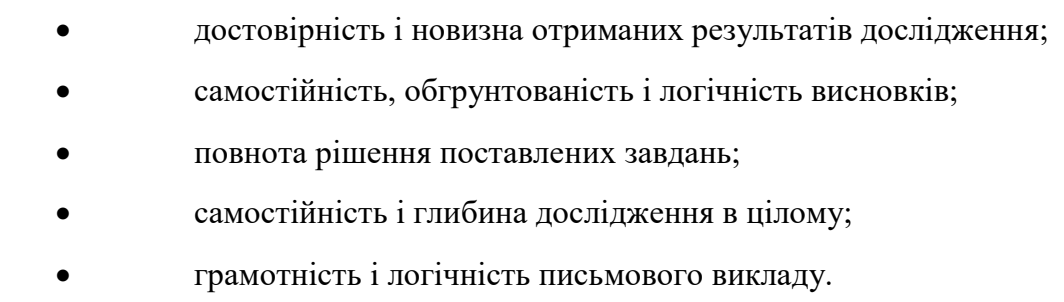 \\
\hline $\begin{array}{c}\text { Презентація результатів } \\
\text { роботи над прикладним } \\
\text { проєктом }\end{array}$ & $\begin{array}{ll} & \text { ясність, логічність, професіоналізм викладу доповіді; } \\
\bullet & \text { наочність і структурованість матеріалу презентації; } \\
\text { • } & \text { вміння коректно використовувати професійну лексику і } \\
\text { понятійно-категоріальний апарат. }\end{array}$ \\
\hline Відповіді на питання & $\begin{array}{cc}\bullet & \text { ступінь володіння темою; } \\
\bullet & \text { ясність аргументації поглядів студента, презентує результати } \\
\text { виконання проєкту; } \\
\bullet \quad \text { чіткість і лаконічність відповідей на питання. } \\
\end{array}$ \\
\hline
\end{tabular}

При реалізації прикладних проєктів, зазвичай, переслідуються цілі, відмінні від дослідних. Тому оцінювання таких проєктів передбачає власний підхід. Аналіз наявних матеріалів з основ проєктної діяльності дозволяє виділити критерії оцінювання прикладних проєктів, які представлені в таблиці 2.

Підсумкова оцінка за проєкт враховує наступне:

- $\quad$ рівень сформованості у студента заявлених в проєктній заявці результатів навчання;

- $\quad$ якість аналізу стану проблеми, що вивчається;

- застосування професійних знань в даній предметній області, зокрема вихід за рамки матеріалу, що викладається під час аудиторних занять;

- самостійність, власну ініціативу;

- рівень та якість виконання поставлених задач;

- $\quad$ якість технічної документації (звіту);

- $\quad$ якість презентації проєктної роботи.

Для групових проєктів додаткової складової підсумкової оцінки може бути оцінка командної взаємодії та індивідуального вкладу учасника проєкту. Підсумкова оцінка являє собою зважену суму складових частин.

Якщо підсумкова оцінка за проєкт, який був включений студенту в індивідуальний план, є «не задовільно», тоді у студента утворюється академічна заборгованість, яка заноситься до рейтингової системи оцінки знань студентів та впливає на прийняття рішень з усіх питань, де враховується наявність у студента академічної заборгованості. Ліквідація академічної заборгованості виконується на кафедрі під керівництвом куратора проєкту.

Перед початком роботи над проєктом доцільно ознайомити студентів 3 критеріями, за якими буде оцінюватися їх проєкт. Критеріями можна користуватися як інструкцією, яка показує, що треба зробити, щоб досягти найкращих результатів. При цьому оцінювання проєкту здійснюється не тільки на етапі представлення та захисту проєкту, але i на проміжних етапах його реалізації.

Набір критеріїв може бути доповнений і скорегований. Тому остаточний вибір критеріїв оцінки проєктної діяльності студентів необхідно робити з урахуванням компетенцій, які освоюються студентами на кожній освітній програмі виходячи з освітніх цілей. 
Критерії, які можна використовувати при оцінюванні прикладних просктів

\begin{tabular}{|c|c|}
\hline $\begin{array}{l}\text { Рекомендовані до оцінювання } \\
\text { складові проєкту }\end{array}$ & Критерії для оцінювання \\
\hline $\begin{array}{c}\text { Постановка проблеми і їі } \\
\text { обгрунтованість, формулювання } \\
\text { цілей і завдань }\end{array}$ & $\begin{array}{l}\text { • } \\
\text { • }\end{array}$ \\
\hline $\begin{array}{c}\text { Зміст проєкту / проєктної } \\
\text { розробки }\end{array}$ & 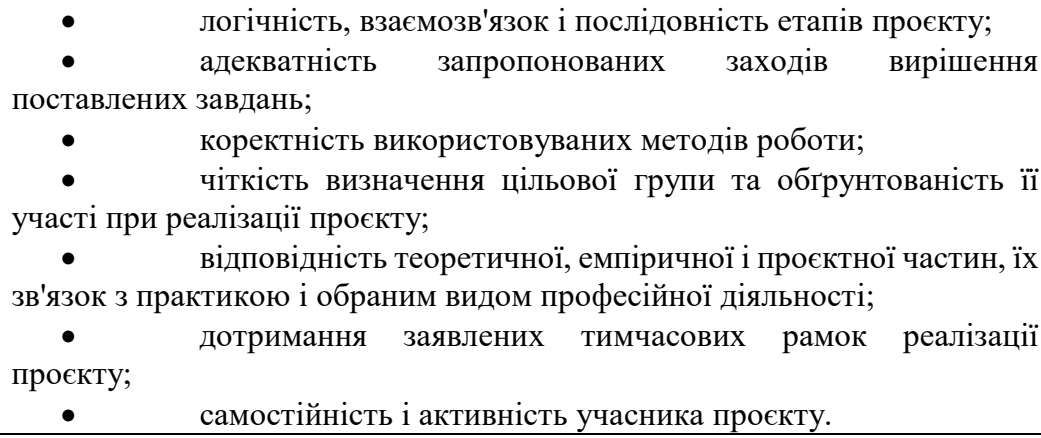 \\
\hline $\begin{array}{l}\text { Результат виконання } \\
\text { прикладного проєкту }\end{array}$ & $\begin{array}{cl}\text { • } & \text { відповідність очікувань від проєкту / планованого } \\
\text { результату отриманого продукту; } \\
\text { • } \\
\text { • } \\
\text { ступінь вирішення заявленої проблеми; } \\
\text { • } & \text { успішність подолання труднощів в реалізації проєкту; } \\
\text { • } & \text { оцінка учасників цільової групи; } \\
\end{array}$ \\
\hline $\begin{array}{c}\text { Презентація результатів роботи } \\
\text { над прикладним проєктом }\end{array}$ & $\begin{array}{ll}\bullet & \text { ясність, логічність, професіоналізм викладу доповіді; } \\
\bullet & \text { наочність і структурованість матеріалу презентації; } \\
\text { в } & \text { вміння коректно використовувати професійну лексику і } \\
\text { понятійно-категоріальний апарат. }\end{array}$ \\
\hline Відповіді на питання & $\begin{array}{lll}\bullet & \text { ступінь володіння темою; } & \\
\bullet & \text { ясність аргументації поглядів } \quad \text { студента, } \\
\text { результати виконання проєкту; } \\
\bullet \quad \text { чіткість і лаконічність відповідей на питання. }\end{array}$ \\
\hline
\end{tabular}

\section{Список використаних джерел}

Красноборова, А. А. (2010). Критерии оценивания проектной деятельности учащихся. Личность, семья и общество: вопрось педагогики и психологии: сб. ст. по матер. II междунар. науч.-практ. конф. (№ 2, ч. I). Новосибирск: СибАК.

Стрекалова, Н. Д. (2013). Методических указаний по подготовке магистерских диссертаций и курсовых работ. СанктПетербург.

Almos, K., Fink, F. \& Krogh, L. (2004). The Aalborg PBL model - Progress, Diversity and Challenges. Aalborg University Press. Crewley, E. F., Malmquist, J., Østlund, S., \& Brodeur, D. (2007). Rethinking engineering education. The CDIO Approach. Springer. Palomba, Catherine A., \& Trudy W. Banta. (1999). Assessment Essentials: Planning, Implementing, and Improving Assessment in Higher Education. San Francosco, Jossey-Bass.

PBLE (Project Based Learning in Engineering). FDTL 3 project involving four institutions: University of Nottingham, Loughborough University, Nottingham Trent University, and DeMontfort University. (2003). Retrieved from http://www.pble.ac.uk

Pedersen, J. R., \& Kofoed, L. B. Challenges of changing a PBL-related curriculum for first year students. Proceedings of 2011 International Conference on Engineering Education. Belfast, UK.

Stachowicz, M. S., \& Kofoed, L. B. Sustainable Design and Renewable Energy in the Engineering Curriculum. Proceedings of 2011 International Conference on Engineering Education. Belfast, UK.

\section{References}

Almos, K., Fink, F. \& Krogh, L. (2004). The Aalborg PBL model - Progress, Diversity and Challenges. Aalborg University Press. Crewley, E. F., Malmquist, J., Østlund, S., \& Brodeur, D. (2007). Rethinking engineering education. The CDIO Approach. Springer. Krasnoborova, A. A. (2010). Kriterii otcenivaniia proektnoi deiatelnosti uchashchikhsia [Criteria for assessing the project activities of students]. Lichnost, semia i obshchestvo: voprosy pedagogiki i psikhologii [Personality, family and society: issues of 
pedagogy and psychology]: sb. st. po mater. II mezhdunar. nauch.-prakt. konf. (Is. 2, part I). Novosibirsk: SibAK [in Russian].

Palomba, Catherine A., \& Trudy W. Banta. (1999). Assessment Essentials: Planning, Implementing, and Improving Assessment in Higher Education. San Francosco, Jossey-Bass.

PBLE (Project Based Learning in Engineering). FDTL 3 project involving four institutions: University of Nottingham, Loughborough University, Nottingham Trent University, and DeMontfort University. (2003). Retrieved from http://www.pble.ac.uk

Pedersen, J. R., \& Kofoed, L. B. Challenges of changing a PBL-related curriculum for first year students. Proceedings of 2011 International Conference on Engineering Education. Belfast, UK.

Stachowicz, M. S., \& Kofoed, L. B. Sustainable Design and Renewable Energy in the Engineering Curriculum. Proceedings of 2011 International Conference on Engineering Education. Belfast, UK.

Strekalova, N. D. (2013). Metodicheskikh ukazanii po podgotovke magisterskikh dissertatcii $i$ kursovykh rabot [Guidelines for the preparation of master's theses and term papers]. Sankt-Peterburg [in Russian].

\section{TIMCHENKO G.N*, NEUSTROIEVA G.*, PONOMARENKO N.**}

*National Technical University “KhPI”, Kharkov, Ukraine

**Ukrainian State University of Railway Transport, Kharkov, Ukraine

\section{PROJECT ACTIVITIES OF STUDENTS AND CRITERIA FOR EVALUATING RESULTS}

The article discusses the issues of organizing students' project work as some modern approach that allows integrating theoretical knowledge and practical skills required for working in modern conditions. Being one of the forms of organizing the educational process, the project activity contributes to improving the quality of education, democratization of the communication style between teachers and students. The purpose of the project activity is to create conditions for the formation of research skills of the students, the development of their creativity and logical thinking. In the presented work practical recommendations for the teachers who want to use projects in their courses are provided.

A system of criteria according to which the student project will be evaluated has been developed. Criteria can be used as instructions that show what needs to be done to achieve the best results. The project evaluation is carried out not only at the stage of presentation and defense of the project, but also at the intermediate stages of its implementation.

Keywords: project work, students, teacher, criterion, assessment, research project, practical project, educational program.

Стаття надійшла до редакції 11.09. 2020 р.

УДК 371.37.052:365.3

https://doi.org/10.33989/2075-146x.2020.26.227656

ІРИНА УСІК

ORCID: 0000-0003-4367-0082

Управління Державної служби якості освіти у Чернігівській області

\section{ЕКСПЕРИМЕНТАЛЬНА ПЕРЕВІРКА ГОТОВНОСТІ КЕРІВНИКІВ ЗАКЛАДІВ ЗАГАЛЬНОЇ СЕРЕДНЬОЇ ОСВІТИ ДО АНТИКРИЗОВОГО МЕНЕДЖМЕНТУ У ПРОЦЕСІ ПІДВИЩЕННЯ КВАЛІФІКАЦІї}

У статті здійснено покроковий аналіз експериментальної перевірки готовності керівників закладів загальної середньої освіти до антикризового менеджменту у процесі підвищення кваліфікації. Підсумовано, що педагогічний експеримент 3 метою діагностування готовності керівників закладів загальної середньої освіти до антикризового менеджменту складався 3 трьох послідовних етапів: діагностичного, констатувального та формувального. Проаналізовано теоретичні дослідження загальних проблем управління. Описано процедуру добору тестових методик, які використовувалися для встановлення стану готовності керівників закладів загальної середньої освіти до антикризового менеджменту у процесі підвищення кваліфікації. З'ясовано, що кожний засіб діагностики, тобто вимірювання, повинен відповідати критеріям оцінки якості, найважливішими з яких є: об'єктивність, надійність, валідність, точність. Репрезентовано цифрові результати констатувального експерименту.

Ключові слова: менеджмент, антикризовий менеджмент, методика, керівник закладу загальної середньої освіти, підвищення кваліфікації, експеримент

Постановка проблеми в загальному вигляді та вказівка на ї̈ зв'язок із важливими науковими чи практичними завданнями. Педагогічний експеримент з метою діагностування готовності керівників закладів загальної середньої освіти до антикризового менеджменту складався з трьох послідовних етапів: діагностичного, констатувального та формувального. Розглянемо детальніше організаційні кроки. Результати діагностичного етапу висвітлено у низці наших публікацій. Тому тут вважаємо за необхідне описати детально процедуру добору тестових 